\title{
PENGARUH KUALITAS LAYANAN TERHADAP KEPUASAN PELANGGAN BENGKEL CAHAYA TERANG DI BUNGKU TENGAH
}

\author{
MOH. SANDY ANDI ANDI KORO \\ MASKURI SUTOMO \\ FARID \\ Program Studi S1 Manajemen, Fakultas Ekonomi, Universitas Tadulako \\ Email: mohsandyandikoro@gmail.com \\ maskuri.sutomo@yahoo.com \\ farid4567@yahoo.com
}

Abstract

This research aims to find out and analyze the influence of the quality of services towards customer satisfaction workshop of Cahaya Terang. This type of descriptive research is causal, using the technique of sampling method of accidental sampling. Data collection was done by disseminating a questionnaire to 90 people or respondents who coincidentally met in the workshop of CahayaTerang. Primary Data obtained from the results of the responses of the respondents through questionnaires, observation and dissemination.

Analysis tools are used multiple linear regression analysis to test the variable with the help of the program SPSS Version 16.0. The results showed that the quality of service of influence simultaneously towards customer satisfaction. Physical evidence of the influential variables are partial and significantly to customer satisfaction. Variable reliability effect partially but not significant toward customer satisfaction. The variable responsiveness effect partially but not significant toward customer satisfaction. Influential guarantee partially variable and significantly to customer satisfaction. Empathy and variable effect in partial and significantly to customer satisfaction.

Keywords: quality of service and customer satisfaction

\section{ABSTRAK}

Penelitian ini bertujuan untuk mengetahui dan menganalisis pengaruh kualitas layanan terhadap kepuasan pelanggan bengkel cahaya terang.Jenis penelitian ini adalah deskriptif kausal, dengan menggunakan teknik pengambilan sampel metode accidental atau convenience sampling.Pengumpulan data dilakukan dengan menyebarkan kuesioner kepada 90 orang atau responden yang secara kebetulan bertemu di bengkel Cahaya Terang.Data primer diperoleh dari hasil tanggapan responden melalui penyebaran kuesioner, dan observasi.Alat analisis yang digunakan adalah analisis regresi linear berganda untuk menguji variabel dengan bantuan program SPSS Versi 16.0.

Hasil Penelitian menunjukkan bahwa kualitas layanan berpengaru secara simultan terhadap kepuasan pelanggan.Variabel bukti fisik berpengaruh secara parsial dan signifikan terhadap kepuasan pelanggan.Variabel kehandalan berpengaruh secara parsial tetapi tidak signifikan terhadap kepuasan pelanggan.Variabel daya tanggap berengaruh secara parsial tetapi tidak signifikan terhadap kepuasan pelanggan.Variabel jaminan berpengaruh secara parsial dan signifikan terhadap kepuasan pelanggan.Variabelempati berpengaruh secara parsial dan signifikan terhadap kepuasan pelanggan.

Kata Kunci: KualitasLayanan,Kepuasan Pelanggan

\section{PENDAHULUAN}

Pada saat ini banyak bermunculan perusahaan besar maupun kecil yang saling berlomba merebut pasar yang seluas-luasnya. Walaupun dengan keadaan perekonomian Negara yang kurang menguntungkan seperti saat ini, dengan adanya perubahan lingkungan bisnis yang demikian cepat serta semakin tinggi persaingan yang terjadi maka perusahaan dituntut untuk mempunyai strategi yang 
tepat untuk mencapai tujuannya. Salah satu contoh persaingan yang cukup terasa di masyarakat saat ini adalah persaingan yang terjadi di dalam usaha bengkel.

Mengingat keberadaan pelanggan adalah faktor penting dalam mencapai tujuan, maka perusahan harus mampu memberikan kepuasan kepada pelanggannya agar dapat memenangkan persaingan. Oleh karena itu dalam melayani pelanggan, maka perusahaan harus mengerti kebutuhan dan keinginan pelanggan. Sehingga pelanggan mendapatkan kepuasan yang optimal, pelanggan memang harus dipuaskan, karena kalau mereka merasa tidak puas dengan pelayanan yang diberikan mereka bisa beralih ke pesaing lainnya.

Pelanggan merupakan fokus utama dalam pembahasan mengenai kepuasan dan kualitas jasa karena dalam hal ini pelanggan memegang peranan cukup penting dalam mengukur kepuasan, terhadap produk ataupun pelayanan yang diberikan perusahaan, dalam mempertahankan karakter dan komitmen kualitas produk (jasa). Seberapa besar toleransi biaya yang harus dikeluarkan dan seberapa besar kualitas telah dinyatakan cukup memuaskan. Hal ini teknisi yang bekerja pada bengkel Cahaya Terang di Bungku Tengah harus benar-benar mengerti yang diinginkan pelanggannya. Sehingga pelanggan merasa diperhatikan dari segi kebutuhan dan keinginannya.

Berdasarkan perkembangan usaha di bagian perbengkelan pada saat ini, pelanggan sangat cenderung melihat kinerja pelayanan dalam memilih layanan jasa. Karena itulah banyak perusahaan otomotif berkembang pada khususnya di bagian jasa bengkel, karena sebagian besar perusahaan melihat ini sebagai peluang usaha yang mempunyai prospek cerah dimasa yang akan datang, serta adanya keinginan pelanggan yang terus meningkat demi memenuhi kebutuhan pelanggan.

Mengingat pada saat ini khususnya di wilayah Bungku Tengah banyak bermunculan usaha yang bergerak di bidang perbengkelan, sehingga untuk saat ini bengkel yang ada di Kecamatan Bungku Tengah berjumlah 25 bengkel. Semakin lama jumlah kendaraan yang berada di Bungku Tengah tiap tahunnya semakin meningkat. Hal ini disebabkan karena meningkatnya kebutuhan masyarakat dalam menggunakan kendaraan khususnya sepeda motor sebagai sarana transportasi. Kendaraan tersebut pasti membutuhkan suatu perawatan berkala demi memperoleh performa yang maksimal.

Salah satu usaha otomotif yang ada di Kecamatan Bungku Tengah yaitu bengkel Cahaya Terang yang didirikan pada tahun 2008 yang beralamat di Jalan Trans Sulawesi. Modal yang digunakan pada saat membuka usaha bengkel motor ini berjumlah Rp 50.000.000 pada tahun 2008, dengan tempat yang digunakan untuk usaha bengkel ini merupakan tempat sendiri sehingga modal yang digunakan hanya untuk membeli perlengkapan dan peralatan sepeda motor. Bengkel Cahaya Terang juga memiliki gudang tempat penyimpanan motor apabila motor pelanggan mengalami kerusakan yang cukup serius sehingga harus bermalam.

\section{KAJIAN LITERATUR DAN PENGEMBANGAN HIPOTESIS}

1. Variabel kualitas layanan secara serempak berpengaruh signifikan terhadap kepuasan pelanggan Bengkel Cahaya Terang Di Bungku

2. VariabelBukti fisik berpengaruh signifikan terhadap kepuasan pelanggan Bengkel Cahaya Terang Di Bungku Tengah.

3. VariabelKehandalanberpengaruh signifikan terhadap kepuasan pelanggan Bengkel Cahaya Terang Di Bungku Tengah.

4. Variabel Daya tanggap berpengaruh signifikan terhadap kepuasan pelanggan Bengkel Cahaya Terang Di Bungku Tengah.

5. Variabel Jaminan berpengaruh signifikan terhadap kepuasan pelanggan Bengkel Cahaya Terang Di Bungku Tengah. 
6. Variabel Empati berpengaruh signifikan terhadap kepuasan pelanggan Bengkel Cahaya Terang Di Bungku Tengah.

Putri (2013) mengenai "Pengaruh Kualitas Pelayanan Terhadap Kepuasan Pelanggan Bengkel Honda Kebon Jeruk (Studi Kasus: PT Istana Kebon Jeruk). Tujuan penelitian ini adalah untuk memahami hubungan dan pengaruh antara kualitas pelayanan terhadap kepuasan pelanggan bengkel Honda Kebon Jeruk. Metode penelitan yang digunakan dipenelitian ini adalah metode kuantitatif. Pengumpulan data yang digunakan dalam penelitian menggunakan instrument kuesioner, dan analisa data menggunakan uji validitas, uji reliabilitas, uji korelasi dan uji regresi. Hasil yang dicapai berdasarkan uji korelasi nilai sebesar 0,883 . Uji regresi yang dilakukan untuk mengetahui seberapa besar pengaruh kualitas pelayanan terhadap kepuasan pelanggan menunjukan bahwa kualitas pelayanan memiliki pengaruh sebesar $77,9 \%$ terhadap kepuasan pelanggan. Simpulan dari penelitian ini adalah kualitas pelayanan terbukti memiliki hubungan dan pengaruh dengan kepuasan pelanggan bengkel Honda Kebon Jeruk.

Kuntari et all (2016) mengenai "Pengaruh Kualitas Pelayanan Terhadap Kepuasan dan Loyalitas Pelanggan (Survei Pada Bengkel PT Astra Internasional Tbk-Daihatsu Malang). Tujuan dari penelitian ini adalah untuk mengetahui suatu Pengaruh Kualitas Pelayanan Terhadap Kepuasan Pelanggan; Pengaruh Kualitas Pelayanan Terhadap Loyalitas Pelanggan; serta Pengaruh Kepuasan Pelanggan Terhadap Loyalitas Pelanggan. Pelaksanaannya, penelitian ini menggunakan penelitian penjelasan (explanatory research) dengan pendekatan kuantitatif. Lokasi penelitian di bengkel PT Astra International Tbk Daihatsu Malang Jalan Ahmad Yani No.175 Malang. Populasi dalam penelitian ini pelanggan bengkel yang melakukan perawatan dan perbaikan mobil di PT Astra International Tbk Daihatsu Malang. Sampel pada penelitian ini berjumlah 124 orang responden. Teknik pengambilan sampel yang digunakan adalah non probability sampling dengan menggunakan teknik purposive sampling dan metode pengumpulan data menggunakan kuesioner. Penelitian ini menggunakan analisis deskriptif dan analisis jalur (path analysis) sebagai alat untuk menganalisis data. Hasil analisis jalur (path analysis) menjadi acuan bahwa variabel Kualitas Pelayanan berpengaruh signifikan terhadap variabel Kepuasan Pelanggan; variabel Kualitas Pelayanan berpengaruh signifikan terhadap Loyalitas Pelanggan dan juga variabel Kepuasan Pelanggan berpengaruh signifikan terhadap Loyalitas Pelanggan.

Masrifani et all (2017) mengenai "Pengaruh Kualitas Pelayanan Terhadap Kepuasan Pelanggan Pada Bengkel Ahass Trio Motor Perintis Banjarmasin. Penelitian ini bertujuan untuk mengetahui apakah kualitas pelayanan yang terdiri dari bukti langsung $\left(\mathrm{x}_{1}\right)$, keandalan $\left(\mathrm{x}_{2}\right)$, daya tanggap $\left(\mathrm{x}_{3}\right)$, jaminan $\left(\mathrm{x}_{4}\right)$ dan empati $\left(\mathrm{x}_{5}\right)$ berpengaruh secara simultan dan parsial terhadap kepuasan pelanggan (Y), serta untuk mengetahui kualitas pelayanan manakah yang berpengaruh dominan terhadap kepuasan pelanggan pada bengkel AHASS Trio Motor Perintis Banjarmasin. Populasi dalam penelitian ini adalah seluruh pelanggan pada tahun 2015 yang berjumlah 34.092 orang. Sampel diambil sebesar 110 pelanggan secara accidental sampling. Analisis dalam penelitian ini dilakukan dengan menggunakan metode regresi linear berganda. Hasil penelitian menunjukkan bahwa kualitas pelayanan yang terdiri dari variabel bukti langsung $\left(\mathrm{x}_{1}\right)$, keandalan $\left(\mathrm{x}_{2}\right)$, daya tanggap $\left(\mathrm{x}_{3}\right)$, jaminan $\left(\mathrm{x}_{4}\right)$ dan empati $\left(\mathrm{x}_{5}\right)$ berpengaruh secara simultan terhadap kepuasan pelanggan $(\mathrm{Y})$. Variabel daya tanggap $\left(\mathrm{x}_{3}\right)$, jaminan $\left(\mathrm{x}_{4}\right)$ dan empati $\left(\mathrm{x}_{5}\right)$ berpengaruh secara parsial terhadap kepuasan pelanggan sedangkan variabel bukti langsung $\left(\mathrm{x}_{1}\right)$ dan keandalan $\left(\mathrm{x}_{2}\right)$ tidak berpengaruh signifikan secara parsial terhadap kepuasan pelanggan.Variabel jaminan $\left(\mathrm{x}_{4}\right)$ merupakan variabel yang dominan mempengaruhi kepuasan pelanggan pada Bengkel AHASS Trio Motor Perintis Banjarmasin. 
Sutrayoga (2012) mengenai "Pengaruh Kualitas Pelayan Terhadap Kepuasan Konsumen Pada Bengkel Mobil Paramitha Auto Graha (PAG) Denpasar. Kualitas pelayanan merupakan hal yang penting untuk diperhatikan agar dapat mempertahankan eksistensi perusahaan. Kualitas pelayanan yang baik maka kepuasan konsumen dapat tercapai. Penelitian ini bertujuan untuk meneliti pengaruh kualitas pelayanan yang terdiri dari bukti fisik, kehandalan, daya tanggap, jaminan dan empati secara simultan dan parsial terhadap kepuasan konsumen pada bengkel mobil Paramitha Auto Graha (PAG) Denpasar yang beralamat di Jl. Ahmad Yani Utara 999, Denpasar. Jumlah sampel yang digunakan berdasarkan teknik accidental sampling adalah 115 responden, serta menggunakan teknik analisis data regresi linier berganda. Hasil analisis yang diperoleh menunjukkan bahwa kualitas pelayanan yang terdiri dari bukti fisik, kehandalan, daya tanggap, jaminan, dan empati secara simultan dan parsial berpengaruh positif dan signifikan terhadap kepuasan konsumen bengkel mobil Paramitha Auto Graha (PAG) Denpasar. Menurut Kotler (2004:7) pemasaran adalah suatu peroses social dan manajerial yang di dalam individu dan kelompok mendapatkan apa yang mereka butuhkan dan inginkan dengan menciptakan, menawarkan, dan menukarkan produk yang bernilai dengan pihak lainnya. Konteks bisnis yang lebih sempit, pemasaran mencakup menciptakan hubungan pertukaran muatan nilai dengan pelanggan yang menguntungkan.

Pelayanan mengandung pengertian yaitu setiap kegiatan atau manfaat yang diberikan oleh suatu pihak kepada pihak lain yang dasarnya tidak berwujud yang tidak pula berakibat kepemilikan sesuatu (Kotler dan Keller 2009:83). Sedangkan menurut Tjiptono (2007) kualitas layanan dapat di artikan sebagai upaya pemenuhan kebutuhan dan keinginan konsumen serta ketepatan penyampaiannya dalam mengimbangi harapan konsumen.

Menurut Parasuraman, et all (dalam Kotler dan Keller, 2009:52) mengidentifikasikan bahwa terdapat lima dimensi yang digunakan konsumen dalam mengevaluasi kualitas layanan yang dikenal dengan istilah SERVQUAL, antara lain adalah:

1. Bukti fisik (tangibles) adalah kemampuan suatu perusahaan dalam menunjukan eksistensinya kepada pihak eksternal.

2. Kehandalan (reliability) yaitu kemampuan suatu perusahaan untuk memberikan layanan sesuai yang dijanjikan secara akurat dan terpercaya.

3. Jaminan (assurance) adalah pengetahuan, kesopansantunan, dan kemampuan para pegawai perusahaan untuk menumbuhkan rasa percaya para konsumen kepada perusahaan

4. Daya tanggap (responsiveness) suatu kebijakan untuk membantu dan memberikan layanan yang cepat dan tepat kepada konsumen, dengan menyampaikan informasi yang jelas.

5. Empati (emphaty) dengan memberikan perhatian yang tulus dan bersifat individual atau pribadi yang diberikan kepada para konsumen dengan berupaya memahami keinginan konsumen.

1. Bukti fisik adalah kemampuan suatu perusahaan dalam menunjukan eksistensinya kepada pihak eksternal. Penampilan dan kemampuan sarana dan prasarana fisik perusahaan yang dapat diandalkan lingkungan sekitarnya merupakan bukti nyata dari layanan yang diberikan oleh pemberi jasa. Hal ini meliputi fasilitas fisik, (misalnya: gedung, gudang dan lain-lain), perlengkapan dan peralatan yang digunakan (tegnologi), serta penampilan pegawainya.

2. Kehandalan yaitu kemampuan suatu perusahaan untuk memberikan layanan sesuai yang dijanjikan secara akurat dan terpercaya. Kinerja harus sesuai dengan harapan konsumen yang berarti ketepatan waktu, layanan yang sama untuk semua konsumen tanpa kesalahan, dan sikap yang simpatik.

3. Daya tanggap suatu kebijakan untuk membantu dan memberikan layanan yang cepat dan tepat kepada konsumen, dengan menyampaikan informasi yang jelas. 
4. Jaminan adalah pengetahuan, kesopansantunan, dan kemampuan para pegawai perusahaan untuk menumbuhkan rasa percaya para konsumen kepada perusahaan. Hal ini meliputi beberapa komponen antara lain komunikasi, keamanan, kredibilitas, kompentensi, dan sopansantun.

5. Empati dengan memberikan perhatian yang tulus dan bersifat individual atau pribadi yang diberikan kepada para konsumen dengan berupaya memahami keinginan konsumen. Dimana suatu perusahaan diharapkan memiliki pengertian dan pengetahuan tentang konsumen untuk memahami kebutuhan secara spesifik, serta memiliki waktu pengoperasian yang nyaman bagi konsumen.

\section{METODE PENELITIAN}

Jenis penelitian ini adalah deskriptif dan kausal. Menurut Arikunto (2008:8) menjelaskan bahwa penelitian deskriptif adalahpenelitian deskriptif adalah riset yang digunakan untuk menguraikan atau menjelaskan situasi permasalahan atau karakteristik dengan penjabaran secara meluas dari objek yang diteliti dan uraian hasil tentang hasil penelitian yang diambil keputusan manajerialnya, dapat berbentuk tabulasi, tabel diagram ataupun gambar. Tujuanuntuk mengetahui keterkaitan hubungan dan pengaruh kualitas jasa atau layanan yang terdiri dari bukti fisik, kehandalan, daya tanggap, jaminan dan empati.

Sedangkan penelitian kausal menurut Rahayu (2001:21) adalah suatu teknik riset yang digunakan untuk menguraikan hubungan antara satu permasalahan dengan kesalahan lainnya, sehingga dapat bersifat seperti hubungan sebab-akibat. Riset kasual sangat cocok untuk tujuan-tujuan seperti memahami variabel-variabel yang menjadi penyebab (variabel independen) dan variabel yang menjadi sebab-akibat (variabel dependen) dari suatu fenomena dan menentukan karakteristik hubungan anatara variabel kausal dan dampak yang diprediksi, terhadap kepuasan pelanggan jasa bengkel Cahaya Terang di Bungku Tengah.

Subjek yang diambil dalam penelitian ini adalah pelanggan yang pernah melakukan servis motor pada layanan bengkel Cahaya Terang di Bungku Tengah. Penelitian ini dilakukan di Bungku Tengah dengan objek penelitian tentang kualitas layanan terhadap kepuasan pelanggan pada bengkel Cahaya Terang di Bungku Tengah. Menurut Sugiyono (2014:38) pengertian objek penelitian adalah sebagai berikut: "segala sesuatu yang dapat berbentuk apa saja yang ditetapkan oleh peneliti untuk dipelajari sehingga diperoleh informasi tentang hal tersebut, kemudian ditarik kesimpulannya".

Adapun lokasi penelitian ini yang di laksanankan pada bengkel Cahaya Terang di Bungku Tengah. Selanjutnya dalam penelitian ini, peneliti hanya membatasi subjek penelitian pada konsumen yang menggunakan jasa bengkel Cahaya Terang di Bungku Tengah. Lokasi yang dijadikan tempat penelitian ini berada disekitar Bungku Tengah yang jaraknya dekat dengan lokasi rumah saya, karena berguna untuk mendapatkan responden secara mudah serta peneliti ingin mengetahui bagaimana kualitas layanan yang diberikan bengkel Cahaya Terang di Bungku Tengah kepada pelanggan.

Adapun jenis data yang digunakan dalam penelitian ini adalah sebagai berikut:

a. Data primer : adalah data yang diperoleh langsung dari sumber asli (tidak melalui media perantara).

Data primer dapat berupa opini subjek (orang) secara individual atau kelompok, hasil observasi terhadap suatu benda (fisik), kejadian atau kegiatan, dan hasil pengujian. Metode yang digunakan untuk mendapatkan data primer yaitu: (1) metode survei dan (2) metode observasi.

b. Data sekunder : adalah sumber data penelitian yang diperoleh peneliti secara tidak langsung melalui media perantara (diperoleh dan dicatat oleh pihak lain). Data sekunder umumnya merupakan bukti, catatan atau laporan historis yang telah tersusun dalam arsip (data dokumenter) yang dipublikasikan dan yang tidak dipublikasikan.

Populasi adalah wilayah generalisasi yang terdiri atas : objek atau subyek yang mempunyai kualitas dan karakteristik tertentu yang ditetapkan oleh peneliti untuk dipelajari dan kemudian ditarik kesimpulannya (Sugiyono, 2017:80). Populasi dalam penelitian ini adalah seluruh masyarakat yang pernah melakukan servis motor pada layanan bengkel Cahaya Terang di Bungku Tengah. 
Sampel adalah bagian dari jumlah dan karaktersik yang dimiliki oleh populasi tersebut.Menurut Sugiyono (2017:81) sampel yang digunakan dalam peneliti ini adalah sebagian dari populasi yang dijadikan responden.Teknik penarikan sampel dalam penelitian ini, dalam menentukan jumlahsampel, maka peneliti menggunakan metode accidental sampling adalah teknik penentuan sampel berdasarkan kebetulan, yaitu siapa saja yang secara kebetulan bertemu dengan peneliti dapat digunakan sebagai sampel, bila dipandang orang kebetulan ditemui itu cocok sebagai sumber data (Sugiyono, 2017:85). Karena jumlah populasi pada tahun 2017 tidak diketahui dengan pasti, maka sampel dihitung berdasarkan indikator yang digunakan.

Sugiyono (2017:91) memberikan saran-saran tentang ukuran sampel untuk penelitian yaitu: bila dalam penelitian akan melakukan analisis dengan multivariate (korelasi/regresi ganda misalnya), maka jumlah anggota sampel minimal 10 kali dari jumlah variabel yang diteliti. Misalnya variabel penelitiannya ada 5 (independen + dependen), maka jumlah anggota sampel $=10 \times 5=50$, Sugiyono (2017:91).

Jumlah variabel dalam penelitian ini adalah 6 variabel yang terdiri dari variabel independen (bukti fisik, kehandalan, jaminan, daya tanggap dan empati) dan variabel dependen (kepuasan pelanggan). Maka jumlah sampel yang ditentukan oleh peneliti 15 × $6=90$ responden.Tehnik pengumpulan data yang dilakukan dengan memberikan daftar pertanyaan untuk diisi oleh responden yaitu pelanggan Bengkel Cahaya Terang Di Bungku Tengah.Pengamatan secara langsung terhadap pelanggan Bengkel Cahaya Terang Di Bungku Tengah untuk memperoleh data yang harus dikumpulkan dalam penelitian.

Analisis regresi berganda digunakan untuk mengukur kekuatan hubungan antara dua variabel atau lebih. Juga menunjukan arah hubungan variabel dependen dengan variabel independen (Ghozali, 2009:86). Model regresi linear berganda terdapat variabel independen X1, X2 dengan variabel dependen Y, maka secara hubungan linear diformulasikan sebagai berikut:

Rumus (Ghozali, 2009:89)

$$
\mathrm{Y}=\mathrm{b} 0+\mathrm{b} 1 \mathrm{X} 1+\mathrm{b} 2 \mathrm{X} 2 \ldots \mathrm{bnXn}+\mathrm{e}
$$

\section{HASIL DAN PEMBAHASAN}

\section{Uji Normalitas Data}

Penggunaan bantuan program statistik SPSS 16.0, hasil uji normalitas data dapat dilihat pada titik sebaran data yang dihasilkan dalam penelitian ini sehingga dapat disimpulkan bahwa data dalam penelitian ini adalah data normal, seperti pada gambar berikut ini:

\section{Gambar .1}

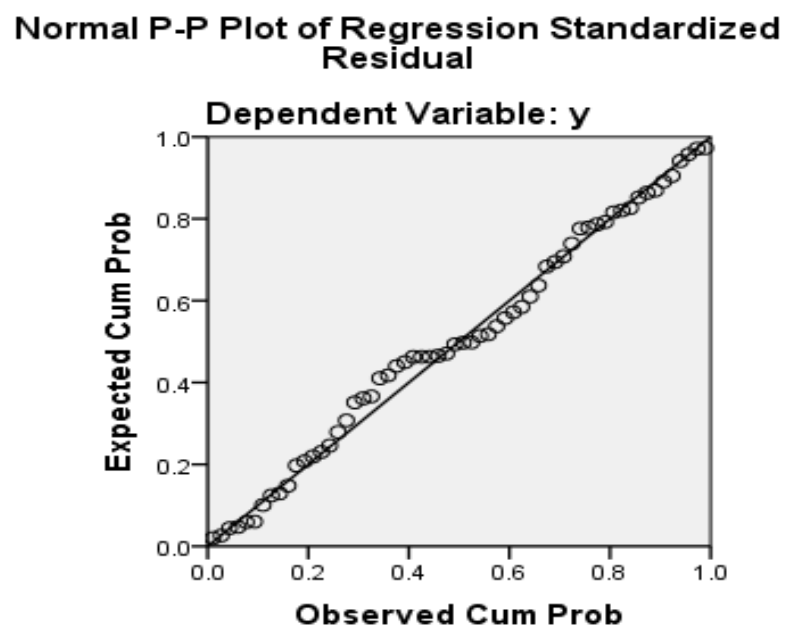


Berdasarkan Gambar 1 di atas, dapat dilihat bahwa data menyebar disekitar garis diagonal, dan mengikuti arah garis diagonal, maka model regresi memenuhi asumsi normalitas.

\section{Uji Multikolinearitas}

Tabel . 1

\begin{tabular}{|ll|r|r|}
\hline \multirow{2}{*}{ Model } & \multicolumn{2}{|c|}{ Collinearity Statistics } \\
\cline { 3 - 4 } & & Tolerance & \multicolumn{2}{|c|}{ VIF } \\
\hline 1 & (Constant) & & \\
& BUKTI FISIK & .934 & 1.070 \\
& KEHANDALAN & .897 & 1.115 \\
& DAYA TANGGAP & .962 & 1.040 \\
& JAMINAN & .997 & 1.003 \\
& EMPATI & .921 & 1.086 \\
\hline
\end{tabular}

Berdasarkan tabel 1 di atas, dapat diketahui bahwa hasil perhitungan Tolerance menunjukan tidak ada variabel independen yang memiliki nilai Tolerance kurang dari 0,10 yang berarti tidakada korelasi antara variabel independen yang nilainya lebih dari $95 \%$. Demikian juga hasil perhitungan Variance Inflation Factors (VIF) besarnya nilai korelasi diantara variabel independen yang ada, menunjukkan bahwa korelasi diantara variabel-variabel independen (bebas) memiliki nilai lebih kecil dari 10. dengan demikian pada tingkat kepercayaan penelitian $95 \%(0,05)$ tidak ditemukan multikolinearitas terhadap variabel-variabel independen penelitian sehingga analisis dapat dilanjutkan.

\section{Uji Heterokedastisitas}

\section{Gambar.2}

Scatterplot

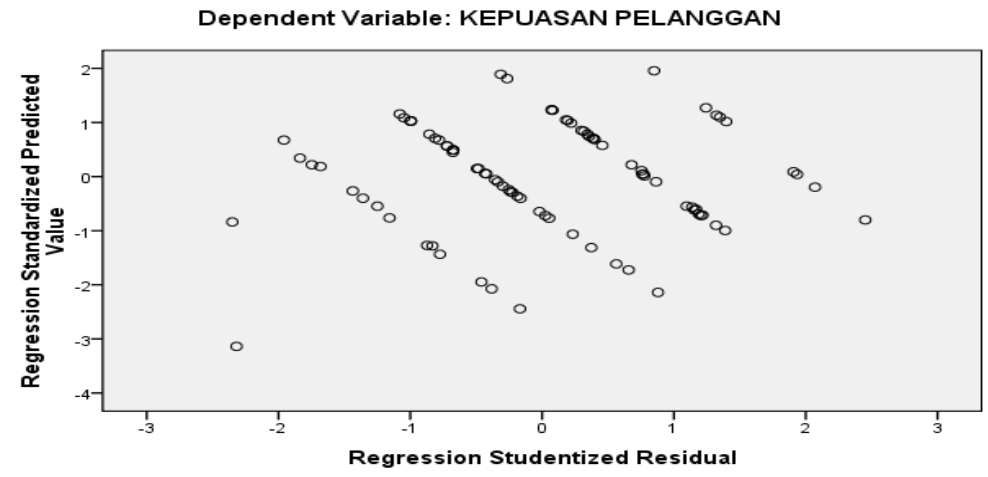

Berdasarkan Gambar 2 di atas, dapat dilihat bahwa titik sebaran data tidak membentuk pola yang jelas, serta titik-titik menyebar di bawah dan di atas angka 0 pada sumbu Y, maka dapat disimpulkan bahwa tidak terjadi heterokedastisitas. Di bawah ini merupakan tabel pembuktian bahwa penelitian ini tidak terjadi heterokedastisitas dengan menggunakan uji glejser. 
JURNAL ILMU MANAJEMEN UNIVERSITAS TADULAKO

Vol. 5, No. 3, September 2019, p. $251-264$

ISSN : 2443-3578 (On Line) / ISSN : 2443-1850 (Print)

\section{Uji Regresi Linear Berganda}

Tabel . 2

\begin{tabular}{|c|c|c|c|c|c|c|}
\hline \multirow[b]{2}{*}{ Model } & & \multicolumn{2}{|c|}{$\begin{array}{l}\text { Unstandardized } \\
\text { Coefficients }\end{array}$} & \multirow{2}{*}{$\begin{array}{c}\text { Standardized } \\
\text { Coefficients } \\
\text { Beta } \\
\end{array}$} & \multirow[b]{2}{*}{$T$} & \multirow[b]{2}{*}{ Sig. } \\
\hline & & B & Std. Error & & & \\
\hline \multirow[t]{7}{*}{1} & (Constant) & .369 & .958 & & .385 & .701 \\
\hline & BUKTI FISIK & .359 & .094 & .373 & 3.829 & .000 \\
\hline & KEHANDALAN & -.053 & .110 & -.048 & -.485 & .629 \\
\hline & DAYA & 0101 & 102 & 0451 & 167 & 611 \\
\hline & TANGGAP & .040 & .100 & .040 & .407 & .041 \\
\hline & JAMINAN & .288 & .105 & .259 & 2.741 & .007 \\
\hline & EMPATI & .274 & .116 & .232 & 2.368 & .020 \\
\hline
\end{tabular}

Analisis regresi linear berganda digunakan untuk mengetahui bagaimana variabel dependen dapat diprediksi melalui dua atau lebih variabel independen sebagai faktor prediktor.Penelitian ini mencoba untuk melihat seberapa besar pengaruh kualitas layanan terhadap kepuasan pelanggan bengkel cahaya terang di Bungku Tengah.

\section{Bukti Fisik $\left(\mathbf{X}_{1}\right)$}

Berdasarkan hasil kuesioner penelitian, dapat diketahui jumlah dan persentase tanggapan responden yang memilih sangat setuju (SS) dengan skor 5, setuju (S) dengan skor 4, ragu-ragu (RR) dengan skor 3, tidak setuju (TS) dengan skor 2, dan sangat tidak setuju (STS) dengan skor 1. Distribusi frekuensi jawaban responden pada variabel bukti fisik yang terdiri atas 3 indikator. Untuk lebih jelasnya dapat ditunjukkan pada tabel berikut ini:

Tabel 3

Frekuensi Jawaban Responden Terhadap Bukti Fisik

\begin{tabular}{|c|c|c|c|c|c|c|c|c|c|c|c|}
\hline \multirow{3}{*}{ Indikator } & \multicolumn{10}{|c|}{ Skor Jawaban $\mathrm{X}_{1}$} & \multirow{3}{*}{ Mean } \\
\hline & \multicolumn{2}{|l|}{5} & \multicolumn{2}{|l|}{4} & \multicolumn{2}{|l|}{3} & \multicolumn{2}{|l|}{2} & \multicolumn{2}{|l|}{1} & \\
\hline & $\mathbf{F}$ & $\%$ & $F$ & $\%$ & $F$ & $\%$ & $\mathbf{F}$ & $\%$ & $F$ & $\%$ & \\
\hline Peralatan & 56 & 62,2 & 31 & 34,4 & 3 & 3,3 & 0 & 0,0 & 0 & 0,0 & 4,59 \\
\hline Lokasi & 41 & 45,6 & 40 & 44,4 & 7 & $a$ & 2 & 2,2 & 0 & 0,0 & 4,33 \\
\hline Fasilitas & 37 & 41,1 & 40 & 44,4 & 11 & 12,2 & 2 & 2,2 & 0 & 0,0 & 4,24 \\
\hline \multicolumn{11}{|l|}{ RATA-RATA } & 4,39 \\
\hline
\end{tabular}

Sumber: Lampiran IV, data diolah kembali

Bengkel Cahaya Terang mempunyai peralatan yang modern yaitu seperti kompresor listrik untuk menambah angin pada ban motor atau mobil. Selain itu kompresor masih memiliki kegunaan yang lain seperti membersihkan debu di setiap mesin atau bodi motor dan mebersihkan filter udara. Kunci pembuka mur mulai ukuran kecil sampai besar, dan scanner motor yang berfungsi untuk 
menganalisa kerusakan mesin yang sudah menggunakan injeksion.Selain itu juga bengkel Cahaya Terang memiliki lokasi yang strategis yaitu tepatnya berada dipinggir jalan sehingga mudah dijangkau oleh masyarakat atau pelanggan bengkel Cahaya Terang. Lokasi bengkel Cahaya Terang merupakan lokasi yang strategis dalam melakukan usaha perbengkelan.Pemilihan lokasi yang strategis menjadi salah satu faktor yang mempengaruhi kesuksesan pemasaran dari sebuah usaha, semakin strategis lokasi yang dipilih, semakin tinggi pula pengaruh terhadap kesuksesan usaha.

Bengkel Cahaya Terang juga memiliki fasilitas fisik, dimana fasilitas fisik adalah segala sesuatu yang berupa benda atau yang dapat di bedakan yang mempunyai peranan dapat memudahkan dan melancarkan suatu usaha tertentu. Untuk fasilitas fisik bengkel Cahaya Terang masih banyaknya pelanggan bengkel Cahaya Terang mengeluh karena fasilitas yang disediakan atau tempat menunggu masih belum tersedia sesuai dengan jumlah banyaknya pelanggan bengkel Cahaya Terang, adapun tempat yang di sediakan berupa kursi yang terbuat dari kayu berbentuk persegi panjang. Apabila bengkel Cahaya Terang dikunjungi banyak pelanggan, maka pelanggan yang tidak mendapatkan tempat duduk harus menunggu sambil berdiri. Berdasarkan Tabel di atas, menunjukkan bahwa skor jawaban mean (rata-rata) tertingi adalah indikator peralatan $\left(\mathrm{X}_{1 \cdot 1}\right)$, sedangkan indikator yang terendah adalah fasilitas $\left(\mathrm{X}_{1 \cdot 3}\right)$. Hal ini menunjukkan bahwa bukti fisik bengkel Cahaya Terang memiliki peralatan yang baik .Namun demikian fasilitas fisik tidak sesuai dengan harapan pelanggan.

\section{Kehandalan $\left(\mathbf{X}_{2}\right)$}

Berdasarkan hasil kuesioner penelitian, dapat diketahui jumlah dan presentase tanggapan responden yang memilih sangat setuju (SS) dengan skor 5, setuju (S) dengan skor 4, ragu-ragu (RR) dengan skor 3, tidak setuju (TS) dengan skor 2, dan sangat tidak setuju (STS) dengan skor 1 . Distribusi frekuensi jawaban responden padavariabel harga yang terdiri atas 3 indikator. Untuk lebih jelasnya dapat ditunjukkan pada table berikut ini:

Tabel 4

Frekuensi Jawaban Responden Terhadap kehandalan

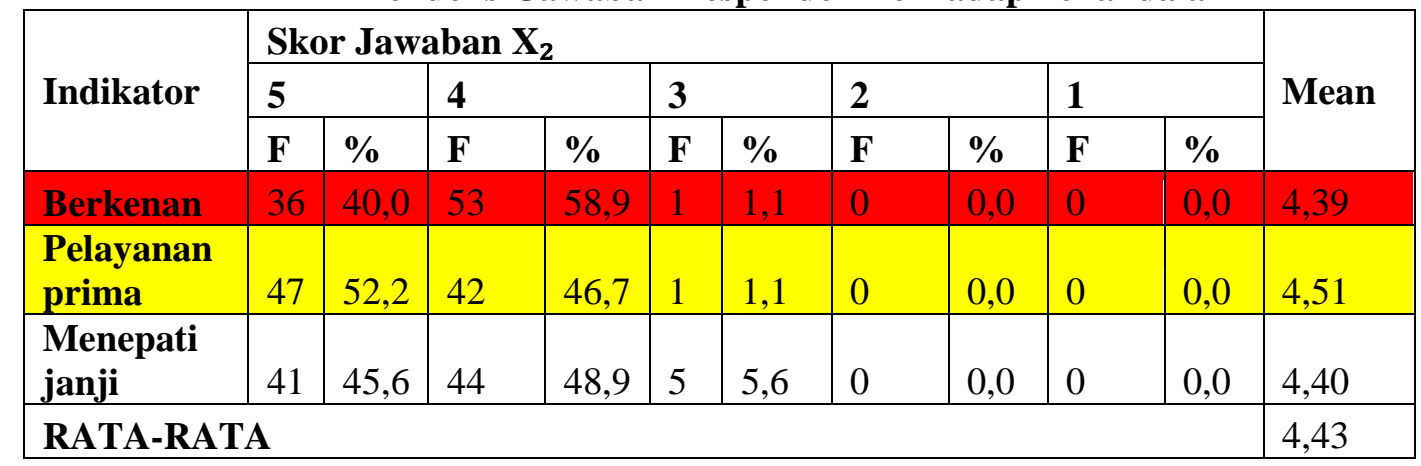

Sumber: Lampiran IV, data diolah kembali

Indikator berkenan di hati pelanggan yaitu disebabkan karena apa yang dijanjikan oleh bengkel Cahaya Terang tidak sesuai dengan harapan yang diinginkan pelanggan bengkel Cahaya Terang seperti penawaran spare part terhadap pelanggan, bengkel Cahaya Terang mempromosikan spare part terhadap pelanggan sangat baik dengan menggunakan merk spare part yang bagus tetapi ternyata setelah mereka menggunakannya, beberapa hari kemudian pelanggan mengeluh karena spare part yang diberikan tidak sesuai dengan yang bengkel Cahaya Terang janjikan sehingga pelanggan merasa kurang puas dan merasa kurang berkenan di hati mereka dengan pelayanan yang diberikan bengkel Cahaya Terang. Pelayanan prima adalah pelayanan yang memenuhi standar kualitas yang sesuai dengan harapan dan kepuasan pelanggan, sehingga dalam pelayanan prima terdapat dua elemen penting yang saling berkaitan yaitu pelayanan dan kualitas. 
Indikator menepati janji adalah dimana bengkel Cahaya Terang mampu memberikan pelayanan sesuai dengan yang mereka janjikan secara tepat waktu, tanpa membuat pelanggan menunggu terlalu lama apabila motor pelanggan sedang di servis, dan tanpa melakukan kesalahan sedikit pun. Berdasarkan Tabel di atas, menunjukkan bahwa skor jawaban mean (rata-rata) tertingi adalah indikator pelayanan prima $\left(\mathrm{X}_{2 \cdot 2}\right)$, sedangkan indikator yang terendah adalah berkenan $\left(\mathrm{X}_{2 \cdot 1}\right)$. Hal ini mengindikasikan bahwa menurut pelanggan,bahwa pelayanan yang di berikan bengkel Cahaya Terang sangat memuaskan. Namun demikian, jasa bengkel Cahaya Terang di Bungku Tengah kurang berkenan di hati pelanggan.

\section{Daya Tanggap $\left(\mathbf{X}_{3}\right)$}

Berdasarkan hasil kuesioner penelitian, dapat diketahui jumlah dan persentase tanggapan responden yang memilih sangat setuju (SS) dengan skor 5, setuju (S) dengan skor 4, ragu-ragu (RR) dengan skor 3, tidak setuju (TS) dengan skor 2, dan sangat tidak setuju (STS) dengan skor 1 . Distribusi frekuensi jawaban responden pada variabel promosi yang terdiri atas 3 indikator. Untuk lebih jelasnya dapat ditunjukkan pada table berikut ini:

\section{Tabel 5}

\section{Frekuensi Jawaban Responden Terhadap Daya Tanggap}

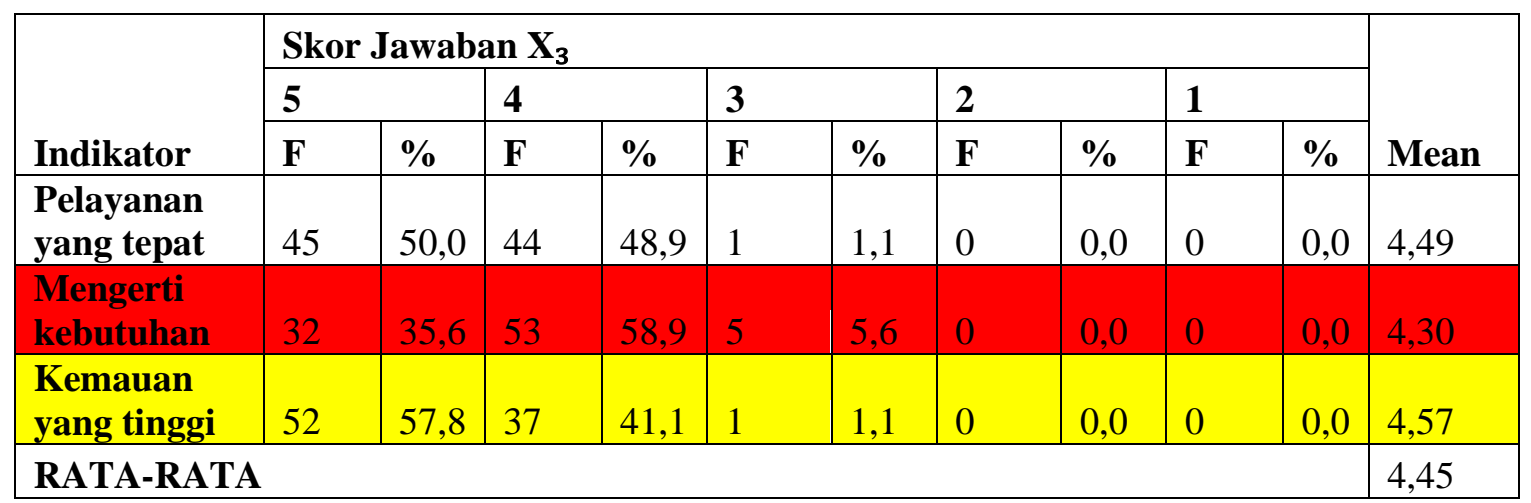

Sumber: Lampiran, data diolah kembali

Indikator pelayanan yang tepat adalah dimana karyawan mampu memberikan layanan yang cepat dan tepat kepada pelanggan dengan menyampaikan informasi yang jelas. Karyawan bengkel Cahaya Terang juga harus memahami dan menguasai keahlian yang dibutuhkan untuk memberikan layanan yang baik terhadap pelanggan. Indikator mengerti kebutuhan adalah indikator yang dimiliki bengkel Cahaya Terang dalam mengukur kualitas layanannya dari hasil penelitian karyawan bengkel Cahaya Terang belum mengerti akan kebutuhan pelanggan sehingga indikator tersebut tidak mempengaruhi kualitas layanan terhadap kepuasan pelanggan. Karyawan bengkel Cahaya Terang hanya memiliki kemauan yang tinggi dalam membantu pelanggan tetapi tidak mengerti akan apa yang di butuhkan pelanggan. Indikator kemauan yang tinggi adalah indikator yang dimiliki bengkel Cahaya Terang dimana karyawan bengkel Cahaya Terang memiliki kemauan yang tinggi untuk membantu pelanggan dan memberikan pelayanan baik dengan penyampaian informasi yang jelas. Karyawan bengkel Cahaya Terang juga sangat memperhatikan pelayananya sehingga tidak pernah mengabaikan dan membiarkan pelanggan.Berdasarkan Tabel di atas, menunjukkan bahwa skor jawaban mean (rata-rata) tertingi adalah indikator kemauan yang tinggi $\left(\mathrm{X}_{3 \cdot 3}\right)$, sedangkan indikator yang terendah adalah megerti kebutuhan $\left(\mathrm{X}_{3 \cdot 2}\right)$. Hal ini mengindikasikan bahwa karyawan bengkel Cahaya Terang memiliki kemauan yang besar dalam membantu pelanggan. Namun demikian karyawan bengkel Cahaya Terang tidak mengetahui kebutuhan pelanggan.

\section{$\operatorname{Jaminan}\left(\mathbf{X}_{4}\right)$}


Berdasarkan hasil kuesioner penelitian, dapat diketahui jumlah dan presentase tanggapan responden yang memilih sangat setuju (SS) dengan skor 5, setuju (S) dengan skor 4, ragu-ragu (RR) dengan skor 3, tidak setuju (TS) dengan skor 2, dan sangat tidak setuju (STS) dengan skor 1 . Distribusi frekuensi jawaban responden pada variabel promosi yang terdiri atas 3 indikator. Untuk lebih jelasnya dapat ditunjukkan pada tabel berikut ini:

Tabel 6

Frekuensi Jawaban Responden Terhadap Jaminan

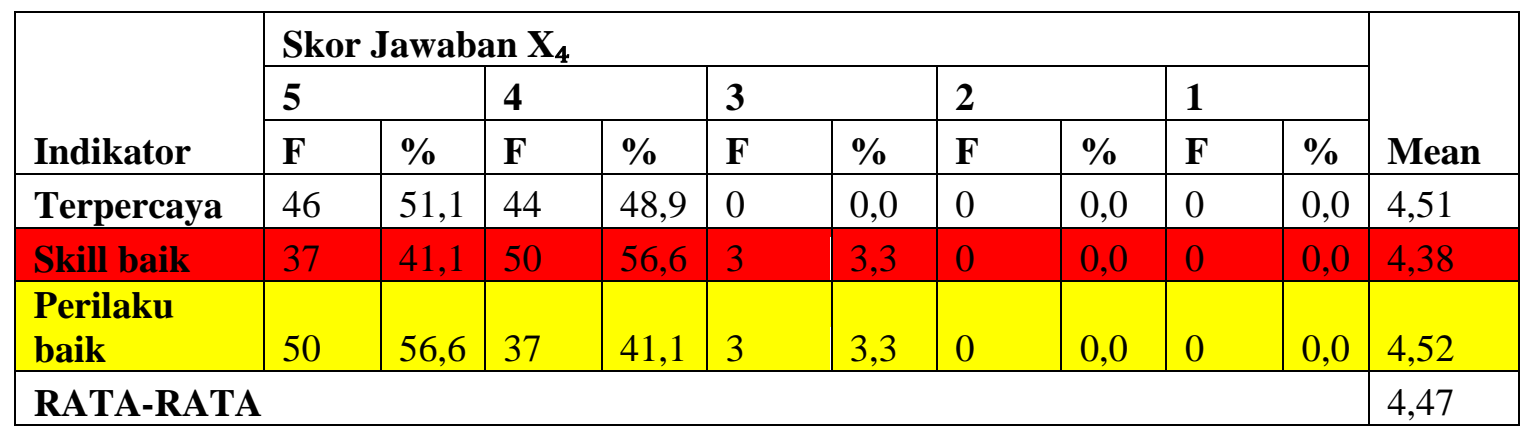

Sumber: Lampiran, data diolah kembali

Indikator terpercaya adalah pelanggan bengkel Cahaya Terang sangat percaya kepada karyawan bengkel Cahaya Terang karena mempunyai kemampuan yang baik dan selalu jujur dalam melakukan pekerjaannya. Semakin tinggi tingkat kepercayaan semakin bagus pula persepsi pelanggan bengkel Cahaya Terang dimata pelanggannya. Akan tetapi karyawan bengkel Cahaya Terang kurang menguasai jasa yang mereka tawarkan atau karyawan bengkel Cahaya Terang kurang mempunyai skill yang baik karena karyawan bengkel Cahaya Terang masih banyak yang baru belajar dan masih dalam pengawasan sehingga kinerja atau skill yang diberikan karyawan kepada pelanggan masih kurang memuaskan. Selain memiliki karyawan yang dapat dipercaya, karyawan bengkel Cahaya Terang memiliki karyawan yang berprilaku baik terhadap pelanggan yang dimaksud dengan perilaku baik adalah dimana seseorang karyawan berinteraksi dengan sopan santun kepada pelanggan. Bengkel Cahaya Terang juga selalu menanamkan kepada karyawan agar selalu mempunyai etika dalam berbicara khususnya kepada pelanggan. Sehingga pelanggan merasa percaya dan yakin kepada karyawan bengkel Cahaya Terang dalam hal memperbaiki kendaraan mereka. Berdasarkan Tabel di atas, menunjukkan bahwa skor jawaban mean (rata-rata) tertingi adalah karyawan bengkel cahaya terang memiliki perilaku baik $\left(\mathrm{X}_{4 \cdot 3}\right)$, sedangkan indikator yang terendah adalah skill yang baik $\left(\mathrm{X}_{4 \cdot 2}\right)$. Hal ini mengindikasikan bahwa karyawan bengkel Cahaya Terang memiliki perilaku yang baik, namun demikian karyawan bengkel Cahaya Terangkurang memiliki skil yang baik.

\section{Empati $\left(\mathbf{X}_{5}\right)$}

Berdasarkan hasil kuesioner penelitian, dapat diketahui jumlah dan persentase tanggapan responden yang memilih sangat setuju (SS) dengan skor 5, setuju (S) dengan skor 4, ragu-ragu (RR) dengan skor 3, tidak setuju (TS) dengan skor 2, dan sangat tidak setuju (STS) dengan skor 1 . Distribusi frekuensi jawaban responden pada variabel promosi yang terdiri atas 3 indikator. Untuk lebih jelasnya dapat ditunjukkan pada tabel 5.5 berikut ini:

Tabel 7

Frekuensi Jawaban Responden Terhadap Empati

\begin{tabular}{|c|c|c|c|c|c|c|c|c|c|c|c|}
\hline \multirow[b]{3}{*}{ Indikator } & \multicolumn{10}{|c|}{ Skor Jawaban $X_{5}$} & \multirow[b]{3}{*}{ Mean } \\
\hline & 5 & & 4 & & 3 & & 2 & & 1 & & \\
\hline & $\mathbf{F}$ & $\%$ & $\mathbf{F}$ & $\%$ & $\mathbf{F}$ & $\%$ & $\mathbf{F}$ & $\%$ & $\mathbf{F}$ & $\%$ & \\
\hline
\end{tabular}




\begin{tabular}{|l|l|l|l|l|l|l|l|l|l|l|l|}
$\begin{array}{l}\text { Perhatian } \\
\text { penuh }\end{array}$ & 45 & 50,0 & 44 & 48,9 & 1 & 1,1 & 0 & 0,0 & 0 & 0,0 & 4,89 \\
\hline $\begin{array}{l}\text { Kenyamanan } \\
\text { pelanggan }\end{array}$ & 40 & 44,4 & 48 & 53,3 & 2 & 2,2 & 0 & 0,0 & 0 & 0,0 & 4,42 \\
\hline $\begin{array}{l}\text { Mengutamakan } \\
\text { kepentingan }\end{array}$ & 56 & 62,2 & 31 & 34,4 & 3 & 3,3 & 0 & 0,0 & 0 & 0,0 & 4,59 \\
\hline \multicolumn{10}{|l|}{ RATA-RATA }
\end{tabular}

Sumber: Lampiran, data diolah kembali

Indikator memberikan perhatian penuh adalah dimana karyawan bengkel Cahaya Terang mampu memberikan perhatian yang lebih terhadap pelanggan sehingga pelanggan merasa dirinya dipentingkan, sekaligus ditumbuhkan kepercayaan dan rasa aman yang diharapkan dapat menimbulkan loyalitas yang tinggi terhadap jasa yang ditawarkan oleh bengkel Cahaya Terang. Dimana seorang karyawan bengkel Cahaya Terang selalu berhadapan langsung dengan pelanggan sehingga mereka harus mengetahui kebutuhan pelanggan dan mengetahui cara merespon keinginan pelanggan.Indikator kenyamanan pelanggan bengkel Cahaya Terang adalah bagian hal yang paling penting untuk kemajuan sebuah bisnis, dimana pandangan pertama memang sangat berpengaruh dalam aktivitas pelanggan kedenpannya, ketika pelanggan mendapatkan respon awal yang buruk dari suatu perusahaan tentunya pikiran pertama me,reka akan mempengaruhi sikap mereka kedepannya.

Hal ini yang dialami bengkel Cahaya Terang dimana pelanggannya kurang nyaman dengan apa yang mereka berikan terhadap pelanggan seperti tidak tersedianya ruang tunggu pada bengkel Cahaya Terang. Indikator mengutamakan kepentingan pelanggan adalah tujuan sebuah bengkel untuk selalu mengutamakan kepentingan atau kebutuhan pelanggan bengkel Cahaya Terang. Dimana karyawan bengkel Cahaya Terang harus mengetahui keinginan pelanggan secara spesifik dari bentuk fisik produk yang diinginkan pelanggan atau pelayanan jasa yang diinginkan oleh pelanggan bengkel Cahaya Terang di Bungku Tengah.Berdasarkan Tabel di atas, menunjukkan bahwa skor jawaban mean (rata-rata) tertingi adalah karyawan bengkel cahaya terang memberikan perhatian penuh kepada pelanggan $\left(\mathrm{X}_{5 \cdot 1}\right)$, sedangkan indikator yang terendah adalah kurang memberikan kenyamanan kepada pelanggan $\left(\mathrm{X}_{5 \cdot 2}\right)$.Hal ini mengindikasikan bahwa karyawan bengkel Cahaya Terang memberikan perhatian penuh kepada pelanggan. Namun demikian karyawan bengkel Cahaya Terang kurang memberikan kenyamanan kepada pelanggan.

\section{KESIMPULAN DAN SARAN}

\section{Kesimpulan}

Berdasarkan hasil analisis dan pembahasan mengenai pengaruh kualitas layanan terhadap kepuasan pelanggan bengkel Cahaya Terang di Bungku Tengah maka dapat disimpulkan sebagai berikut:

1. Kualitas layanan yang terdiri dari Bukti Fisik, Kehandalan, Jaminan, Daya Tanggap, dan Empatisecara simultan berpengaruh signifikan terhadap kepuasan pelanggan bengkel Cahaya Terang di Bungku Tengah.

2. Variabel Bukti Fisik berpengaruh positif dan signifikan terhadap kepuasan pelanggan bengkel Cahaya Terang di Bungku Tengah

3. Variabel Kehandalan berpengaruh positif tetapi tidak signifikan terhadap kepuasan pelanggan bengkel Cahaya Terang di Bungku Tengah.

4. Variabel Daya Tanggap berpengaruh positif tetapi tidak signifikan terhadap kepuasan pelanggan bengkel Cahaya Terang di Bungku Tengah

5. Variabel Jaminan berpengaruh positif dan signifikan terhadap kepuasan pelanggan bengkel Cahaya Terang di Bungku Tengah 
6. Variabel Empati berpengaruh positif dan signifikan terhadap kepuasan pelanggan bengkel Cahaya Terang di Bungku Tengah

\section{Saran- Saran}

Adanya sejumlah keterbatasan dalam penelitian ini serta hasil pengamatan dan pengetahuan yang diperoleh peneliti pada saat penelitian, maka peneliti menyarankan hal-hal berikut:

1. Kepada pihak bengkel Cahaya Terang di Bungku Tengah, dihrapkan dapat lebih meningkatkan variabel kualitas layanan yang terdiri dari bukti fisik, kehandalan, daya tanggap, jaminan dan empati yang telah terbukti berpengaruh signifikan terhadap kepuasan pelanggan.

2. Penelitian selanjutnya diharapkan pula dapat menambah jumlah sampel penelitian serta memperluas wilayah sampel penelitian, dandapat melakukan penelitian di Kecamatan atau Kabupaten lain sehingga nanti hasilnya dapat digeneralisasikan untuk lingkup yang lebih luas.

3. Selain itu, walaupun hasil penelitian ini menunjukkan bahwa semua variabel independen berpengaruh secara positif terhadap variabel dependen. Namun, peneliti menyarankan agar penelitian selanjutnya menguji kembali variabel independen ini untuk lebih memastikan apakah variabel independen ini mempengaruhi kepuasan pelanggan bengkel Cahaya Terang di Bungku Tengah.

\section{REFERENSI}

Arikunto, Suharsimi. 2008. Prosedur Penelitian :Suatu Pendekatan Praktek. (Edisi Keempat) Jakarta: Rineka Cipta

Ghozali, Imam, 2009. Aplikasi Analisis Multivariate Dengan Program SPSSS, Cetakan Ke IV, Badan Penerbit Universitas Diponegoro, Semarang.

Kotler, Philip dan Keller Kevin Lane. 2009. Manajemen Pemasaran. Jilid I. Edisi ke 13,Jakarta: Erlangga

Kotler,Philip (2004) Manajemen Pemasaran 2, Edisi Milenium,Jakarta:PT. Ikrar Mandiri

Kuntari, et all.2016.Pengaruh Kualitas Pelayanan Terhadap Kepuasan dan Loyalitas Pelanggan (Survei Pada Bengkel PT Astra Internasional Tbk-Daihatsu Malang).Jakarta.

Masrifani, et all.2017.Pengaruh Kualitas Pelayanan Terhadap Kepuasan Pelanggan Pada Bengkel Ahass Trio Motor Perintis Banjarmasin.DINAMIKA EKONOMI. Jurnal Ekonomi dan Bisnis Vol.10 No. 1 Maret 2017.Banjarmasin.

Parasuraman, Valerie A. Zeithaml. Leonard Berry.1985.A conceptual Modelof Service Quality and Its Implication for Future Research. Journal of Marketing, Volume 49.

Putri. 2013. Pengaruh Kualitas Pelayanan Terhadap Kepuasan Pelanggan Bengkel Honda Kebon Jeruk (Studi Kasus: PT Istana Kebon Jeruk).Universitas Bina Nusantara Jurusan Marketing Communication peminatan Public Relation.Jakarta.

Rahayu, E. A. 2001. Perbandingan Daya Tumbuh Dan Kesempurnaan Tumbuh Stek Rumput Gajah Yang Disimpan Dengan Metode Berbeda.Skripsi. Fakultas Peternakan.Institut Pertanian Bogor.

Sugiyono, 2017. Metode Penelitian Kuantitatif, Kualitatif, dan R\&D. Bandung :Alfabeta. 
JURNAL ILMU MANAJEMEN UNIVERSITAS TADULAKO

Vol. 5, No. 3, September 2019, p. $251-264$

ISSN : 2443-3578 (On Line) / ISSN : 2443-1850 (Print)

Sugiyono. (2014). Metode Penelitian Pendidikan Pendekatan Kuantatif,kualitatif, dan R and B.Bandung:Alfabta.

Sutrayoga.2012.Pengaruh Kualitas Pelayanan Terhadap Kepuasan Konsumen Pada Bengkel Mobil Paramitha Auto Graha (PAG) Denpasar.Fakultas Ekonomi Universitas Udayana (Unud), Bali, Indonesia

Tjiptono,Fandy. 2007. Strategi Pemasaran. Edisi Kedua. Yogyakarta: Andi. 